\title{
Reduction of hexavalent cromium by Serratia marcecens immobilized on active carbon and their potencial use in bioremediation.
}

\section{Reducción de cromo hexavalente, por Serratia marcecens inmobilizada en carbon activado y su potencial uso en biorremediacion.}

\author{
Víctor Campos ${ }^{1 *}$, Rubén Moraga ${ }^{2}$, Ítalo Fernández ${ }^{1}$, Francisco Yáñez $^{3}$, Ariel Valenzuela ${ }^{3}$ \& María- \\ AngÉLICA MONDACA ${ }^{1}$ \\ 1'Departamento de Microbiología, Facultad de Ciencias Biológicas. Universidad de Concepción. Casilla 152-C. Concepción, \\ Chile. \\ ${ }^{2}$ Departamento de Ciencias del Mar, Universidad Arturo Prat, Casilla 121, Iquique, Chile. \\ ${ }^{3}$ Departamento de Oceanografía, Facultad de Ciencias Naturales y Oceanográficas. Universidad de Concepción. Casilla152-C. \\ Concepción, Chile. \\ *E-mail:vcampos@udec.cl
}

\section{RESUMEN}

S. marcescens, cepa tolerante a cromato, presenta la capacidad de formar biopeliculas y transformar el $95 \%$ de cromato presente en el medio a $\mathrm{Cr}(\mathrm{III})$, compuesto menos tóxico, después de $48 \mathrm{~h}$ de incubación, a una velocidad de transformación de $1.67 \mathrm{mg} \mathrm{L}^{-1} \mathrm{~h}^{-1}$. S. marcescens puede ser utilizado en biorremediation de residuos contaminados con cromato.

Chromium pollution due to wastewater discharges from manufacturing and domestic activities may pose a serious threat to human health and environmental quality (Campos et al. 2002). Indeed, $\mathrm{Cr}(\mathrm{VI})$ has been identified as a key contaminant due to its toxicity (Park et al. 2002). Biological reduction of $\mathrm{Cr}(\mathrm{VI})$ to $\mathrm{Cr}(\mathrm{III})$ is an attractive alternative to treat chromium contaminated effluents and soils, since the latter presents much lower toxicity (McLean \& Beveridge 2001). A number of both aerobic and anaerobic bacteria presenting chromate reducing enzymatic ability have been identified (Shanker et al. 2005).

In particular, chromate-resistant S. marcescens bacteria, isolated from a tannery effluent has been shown to present chromate reducing activity (Campos et al. 2005) and could grow in the presence of a wide range of industrial contaminants. The use of such $\mathrm{Cr}(\mathrm{VI})$ reducing bacteria in chromium-contaminated soil and water bioremediation would be enhanced if $S$. marcescens was able to form stable biofilms. Biofilm formation appears to be a widespread attribute of bacteria and may allow increased survival ability under stressful conditions such as low nutrients or antimicrobial treatments (Mah and O'Toole 2001). Indeed, immobilised cells as a biofilm on inert supports enable high biomass retention in bioreactors and are frequently found in industrial applications (Nicolella et al. 2000). Usually, cell immobilisation is achieved on inert support featuring large specific surface area, where biofilms are formed (Friedman \& Kolter 2004).

The aim of this work was to evaluate the efficiency of chromate reduction by $S$. marcescens, in Biofilm and free cells, under aerobic conditions and evaluated their biotechnological potential.

Biofilm formation was monitored by Scanning Electron Microscopy. Figure 1a to 1c, show biofilm development by $S$. marcescens cultured in the presence of granular activated carbon, where after $3 \mathrm{~h}$ incubation, small cells are randomly distributed on the surface of active carbon, with spaces noncolonized (Figure 1a). After 6h of incubation, bacteria were anchored to the carbon surface and to each other by means of fibrils, in order to bridge the space between bacteria. After 72 hours incubation, a mature biofilm was detected, with attached bacteria that excreted extracellular polysaccharides covering sessile cells and serving as a matrix for further biofilm formation.

In addition, Scanning Electron-microscopy revealed the presence of thin fibrillar pili at the cells surface (Figure 1a and 1b). These particular pili are similar to curli structures described by Olsen et al. (1989). The Curli (Pili or Microfibrillar) seem to be an envelope structure of major importance for surface colonization (Gualdi et al. 2008), 
because provides stability to the biofilm, allowing strong hydrodynamic conditions support on prolonged culture or without interruption (Donlan \& Costerton 2002).

As seen in Figure 1c, some cells were able to produce copious amounts of extracellular polysaccharides. The polymeric matrix observed appears similar to that previously described in other microorganisms (Kobayashi 2007; Lerner et al. 2009). These polysaccharides suffer different colloidal interactions, linking bacteria to the surface by a combination of weak chemical bonds, dipole interactions, and hydrophobic interactions (Hall-Stoodley et al. 2004). In this respect, BATH tests showed that $S$. marcescens is highly hydrophobic (viz. hydrophobicity value around 67\%) and, therefore, present a great affinity to solid surfaces.

Figure 2 shows the increase in the number of immobilised $S$. marcescens as the biofilm formation progresses. The results show counts of about $10^{9}$ (CFU/g carbon) and $5 \times 10^{7}$ (bacteria/ $\mathrm{cm}^{2}$ ), after $72 \mathrm{~h}$ of incubation. The rapid biofilm formation by $S$. marcescens (48-72 h) can be accounted by the multiplication of sessile cells, and the adherences of new planktonic cells to the carbon surface.
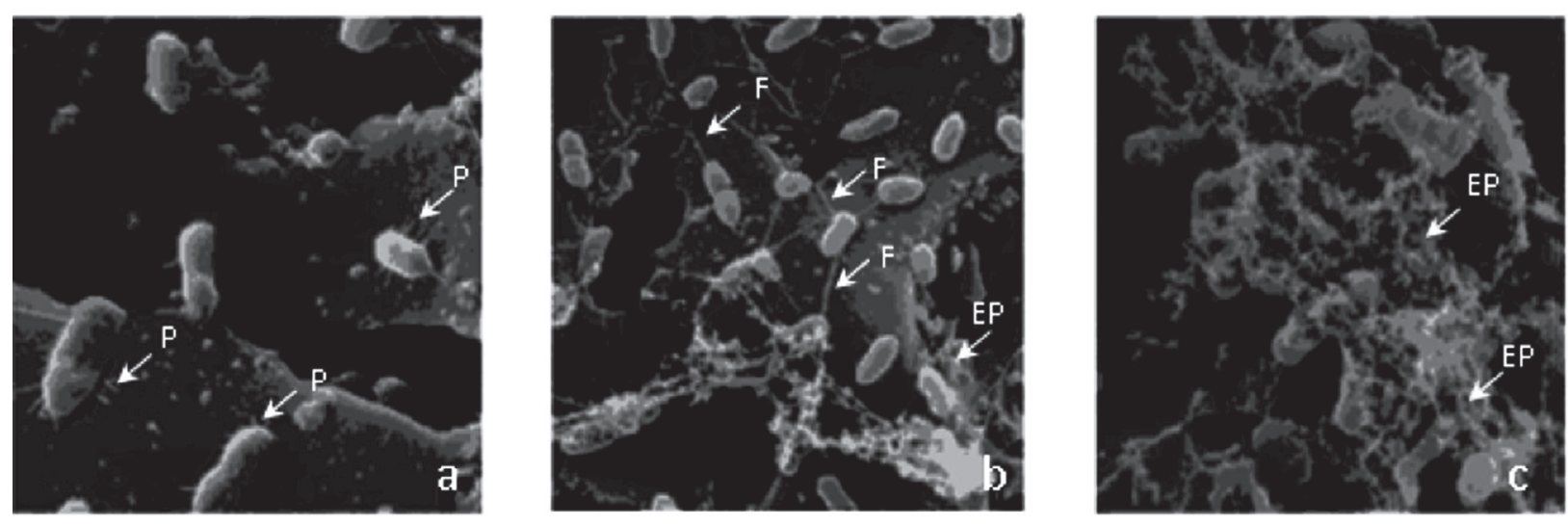

Figure 1. Biofilm formation of S. marcescens on activated carbon (a) 3h (b) 24 (c) 72 h. A= 7500x, P: Pilli: F: Microfibrils; EP: Exopolysacharides.

Figura 1. Formación de biopelicula de S. marcescens sobre carbón activado. (a) 3h (b) (b) 24 (c) 72 h. A= 7500x, P: Pilli: F: Microfibrils; EP: Exopolysacharides.

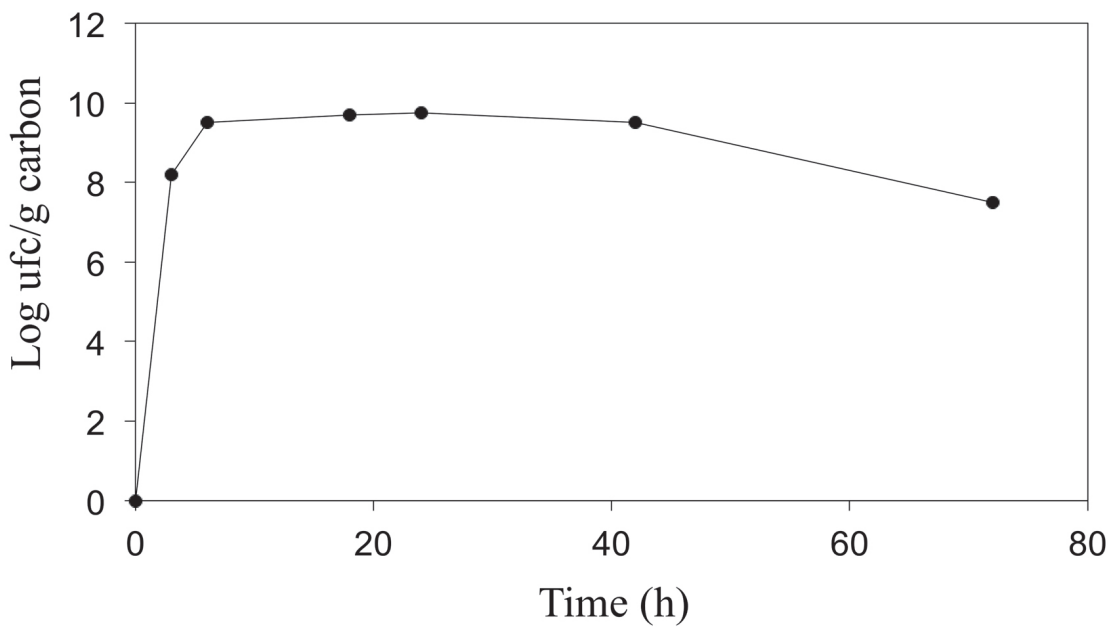

FIGURE 2. Growth of $S$. marcescens on activated carbon. (•) Bacterial Growth, expressed as Log CFU/mL.

Figura 2. Crecimiento de $S$. marcescens sobre carbón activado. (•) Crecimiento bacteriano, expresado en Log UFC/mL. 
The chromate tolerance study, demonstrated that $S$. marcescens could grow without any inhibition at a chromate concentration of $2 \mathrm{mM}$. It must be emphasized that resistance chromate is not a common property of Serratia spp. or others enterobacteriaceaes.

The chromate bio-reduction analyses were performed using HPLC/HG/ASS. Chromate reduction by immobilised $S$. marcescens is illustrated in Figure $3 \mathrm{a}$. These cells were able to reduce $\mathrm{Cr}(\mathrm{VI})$ under aerobic conditions, leading to about $95 \% \mathrm{Cr}(\mathrm{VI})$ conversion to $\mathrm{Cr}(\mathrm{III})$ after $48 \mathrm{~h}$ culture. Mass balance shows that $\mathrm{Cr}(\mathrm{VI})$ was transformed to $\mathrm{Cr}(\mathrm{III})$ at a rate $1.67 \mathrm{mg} \mathrm{L}^{-1} \mathrm{~h}^{-1}$. As a comparison, S. marcescens (planktonic) were cultured in similar conditions yielding a $80 \%$ reduction in $\mathrm{Cr}(\mathrm{VI})$ to $\mathrm{Cr}(\mathrm{III})$, after $48 \mathrm{~h}$ and at cell concentration around $3 \times 10^{9}(\mathrm{CFU} / \mathrm{mL})$ (Figure $\left.3 \mathrm{~b}\right)$, with a transformation rate of $1.40 \mathrm{mg} \mathrm{L}^{-1} \mathrm{~h}^{-1}$. No chromate reduction was observed in $\mathrm{KSC}$ media without bacteria.
Similar results were reported by Campos et al. (2005), with reduction percentages higher $(86 \%)$, using nonimmobilized $S$. marcescens. This difference is due to errors pre-treatment of the samples for chemical analyses. Also the ability to reduce chromate of this strain may be a secondary activity of a soluble reductase enzyme with a quite different physiological role. However, the immobilized cells were more efficient in transform chromate present in the medium.

It can be concluded that $S$. marcescens could be effectively used to remove chromate from highly contaminated soils and waters, given its ability to reduce $\mathrm{Cr}$ (VI) to $\mathrm{Cr}$ (III) and form a stable biofilm. Finally, it must be emphasised that since this bacteria was isolated from a natural environment, it should present resistance not only to chromium but also to other contaminants present in such conditions.

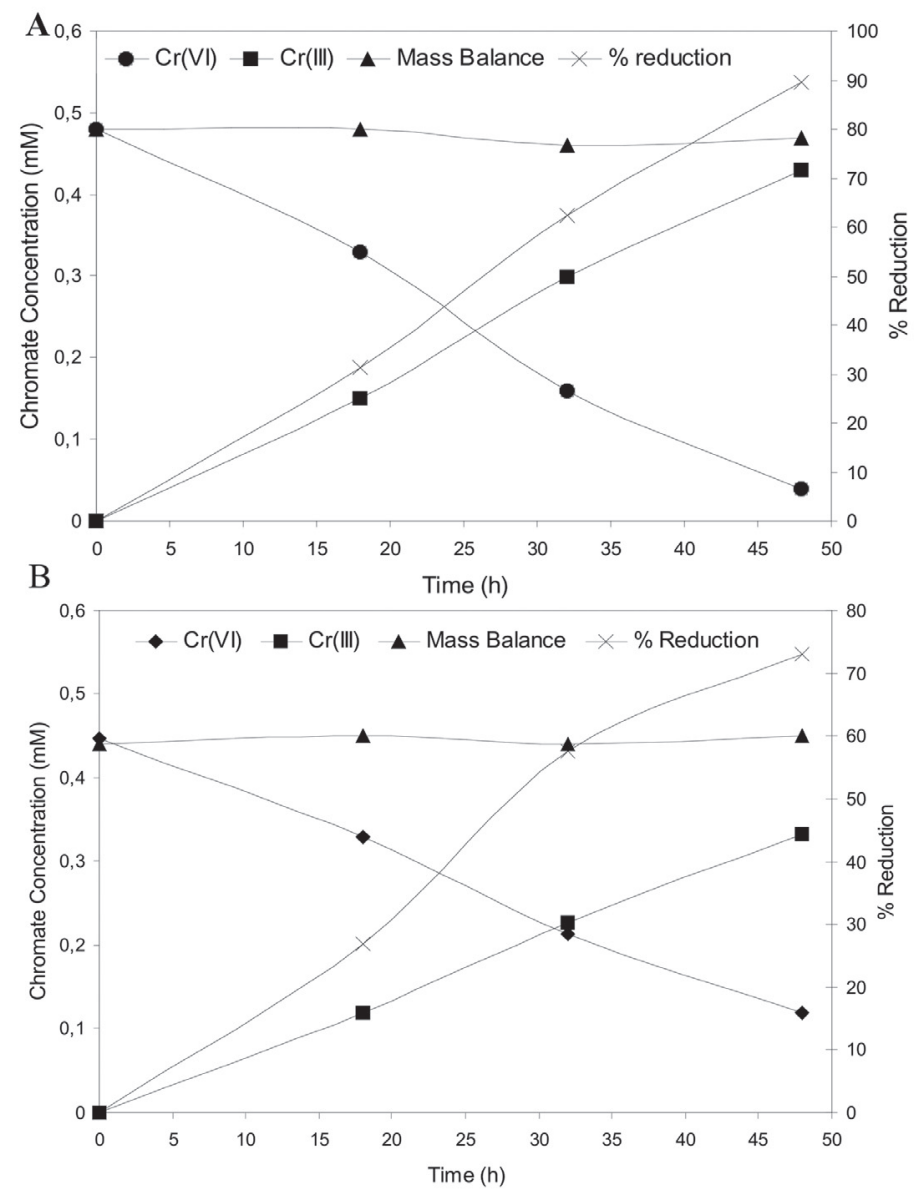

Figure 3. Chromium (VI) reduction by $S$. marcescens, with initial concentration $0.5 \mathrm{mmol} \mathrm{L}^{-1} \mathrm{~K}_{2} \mathrm{CrO}_{4}$ at $30^{\circ} \mathrm{C}$. A) Immobilized cells on activated carbon B) Plancktonic cells.

Figura 3. Reducción de cromo (VI) por $S$. marcescens, con una concentración inicial de $0.5 \mathrm{mmol} \mathrm{L}^{-1}$ de $\mathrm{K}_{2} \mathrm{CrO}_{4}$ a $30^{\circ} \mathrm{C}$. A) Células inmovilizadas en carbón activado B) Células planctónicas. 


\section{ACKNOWLEDGEMENTS}

This research was supported by DIUC project $\mathrm{N}^{\circ} 211.36 .39 .1$, Universidad de Concepción.

\section{REFERENCES}

Campos, V.L., Escalante, G., Yañez, J., Zaror, C. \& Mondaca, M.A. 2005. Isolation of arsenite-oxidizing bacteria from a natural biofilm associated to volcanic rocks of Atacama Desert, Chile. Journal Basic of Microbiology 49 (S1):S93-97.

Campos, V.L., Yañez, J., Zaror, C. \& Mondaca, M.A. 2002. Chromate reduction in Serratia marcescens isolated from tannery effluents. Bulletin of Environmental Contamination and Toxicology 75:400-406.

Donlan, R.M. \& Costerton, J. 2002. Biofilms: survival mechanisms of clinically relevant microorganisms. Clinical Microbiology Reviews 15:167-93.

Friedman, L. \& Kolter, R. 2004. Genes involved in matrix formation in Pseudomonas aeruginosa PA14 biofilms. Molecular Microbiology 3:675-690.

Gualdi, L., Tagliabue, L., Bertagnoli, S., Ieranò, T., De Castro, C. \& Landini, P. 2008. Cellulose modulates biofilm formation by counteracting curli-mediated colonization of solid surfaces in Escherichia coli. Microbiology 154:20172024.

Hall-Stoodley, L., Costerton, J. \& Stoodley, P. 2004. Bacterial biofilms: from the natural environment to infectious diseases. Nature Review Microbiology 2:95-108.

Kobayashi, K. 2007. Bacillus subtilis pellicle formation proceeds through genetically defined morphological changes. Journal of bacteriology 189:4920-4931.

Lerner, A., Castro-Sowinski, S., Lerner, H., Okon, Y. \& Burdman, S. 2009. Glycogen phosphorylase is involved in stress endurance and biofilm formation in Azospirillum brasilense Sp7. FEMS Microbiology Letters 300:75-82.

Maн, T.F. \& O'Toole, G.A. 2001. Mechanisms of biofilm resistance to antimicrobial agents. Trends in Microbiology 9: 34-39.

Mclean, J. \& Beveridge, T. 2001. Chromate reduction by a pseudomonad isolated from a site contaminated with chromated copper arsenate. Applied Environmental of Microbiology 67:1076-1084.

Nicolella, C., Marck, C., Van Loosdrecht, C. \& Heijnen, S. 2000. Particle -based biofilm reactor technology. TIBTECH 18:312-322.

Olsen, A., Jonsson, A. \& Normar, S. 1989. Fibronectin binding mediated by a novel class of surface organelles on Escherichia coli. Nature 338:652-655.

Park, C., Gonzalez, D., Ackerley, D., Keyhan, M. \& Matin, A. 2002. Molecular engineering of soluble bacterial proteins with chromate reductase activity. In: M. Pellei, A. Porta and R.E. Hinchee, Editors, Remediation and Beneficial Reuse of Contaminated Sediments, vol. 3, Batelle Press, Columbus.

Shanker, A.K., Cervantes, C., Loza-Tavera, H. \& Avudainayagam, S. 2005. Chromium toxicity in plants. Environmental International 31:739-753.

Recibido: 26.08 .12

Aceptado: 03.10.12 